\title{
ANATOMICAL PARAMETERS OF THE ACETABULUM IN HEAVY VEHICLE OPERATORS
}

\author{
Dejan Jeremic ${ }^{1}$, Maja Vulovic ${ }^{1}$, Ivana Zivanovic Macuzic ${ }^{1}$, Anita Ivosevic ${ }^{2}$, Vesna Grbovic ${ }^{4}$, Igor Sekulic ${ }^{3}$, Dusica Djordjevic ${ }^{4}$ \\ ${ }^{1}$ Department of Anatomy, Faculty of Medical Sciences, University of Kragujevac, Serbia \\ ${ }^{2}$ Department of Internal Medicine, Faculty of Medical Sciences, University of Kragujevac, Serbia \\ ${ }^{3}$ Institute of Radiology, Military Medical Academy, Belgrade, Serbia \\ ${ }^{4}$ Department of Physical Medicine and Rehabilitation, Faculty of Medical Sciences, University of Kragujevac, Serbia

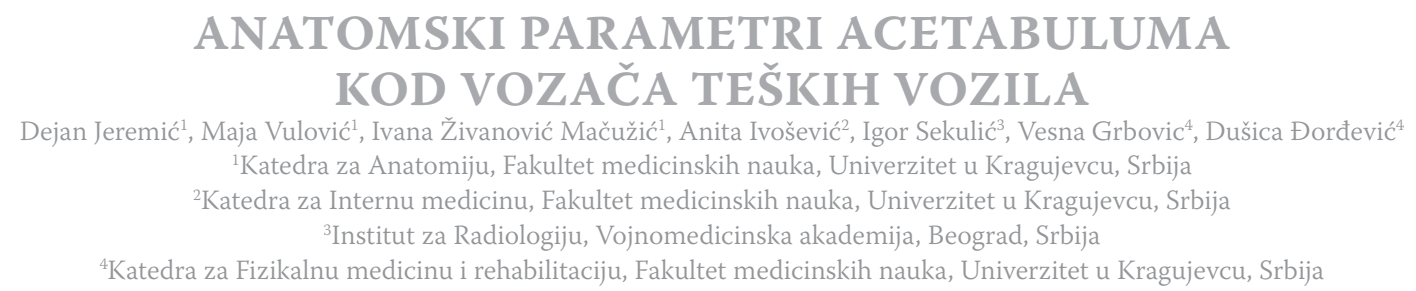

Received / Primljen: 02.05.2016.

Accepted / Prihvaćen: 20.05.2016.

\begin{abstract}
It has been suggested that long-term exposure by heavy vehicle operators to whole-body vibration (WBV) may be related to an increased risk of pathological changes in the anatomical parameters of the hip. The aim of this study was to explore the difference in anatomical parameters of acetabulum in drivers of heavy vehicles (experimental group; $n=60$ ) and subjects who have not been exposed to WBV (control group; $n=60$ ). The anteroposterior radiographic view of the hips was used to measure the following parameters: the vertical centre edge (VCE), the 'horizontal toit externe' angle (HTE), the neck shaft angle (NSA) and the acetabular depth (AD). Compared with the control group, the mean VCE angle values and $A D$ were significantly lower, while the average HTE and NSA values were significantly higher in the experimental group. This study supports the hypothesis that exposure to whole-body vibration during operation of a vehicle causes an increased risk of acetabular dysplasia.
\end{abstract}

Keywords: Whole-body vibration, Drivers, Hip joint, Dysplasia

\section{SAŽETAK}

S obzirom da izloženost vibracijama celog tela, usled upravljanja teškim vozilima, može biti u vezi sa povećanim rizikom od nastanka patoloških promena zgloba kuka, cilj studije je bio da ispita razlike $u$ anatomskim parametrima acetabuluma kod vozača teških vozila (eksperimentalna grupa; n=60) i ispitanika koji nisu izloženi vibracijama (kontrolna grupa; $n=60$ ). Anteriorno-posteriorni radiografski snimak kuka korišćen je za merenje sledećih parametara: ugao lateralizacije femura (Vibergov ugao), nagib krova acetabuluma, kolodijafizalni ugao femura $i$ dubina acetabuluma. Srednje vrednosti Vibergovog ugla $i$ dubine acetabuluma bile su značajno niže, a nagib acetabuluma $i$ kolodijafizalni ugao značajno viši, u eksperimentalnoj nego u kontrolnoj grupi. Studija potvrduje hipotezu da izloženost vibracijama celog tela predstavlja rizik za nastanak acetabularne displazije.

Ključne reči: Vibracije celog tela, Vozači, Zglob kuka, Displazija
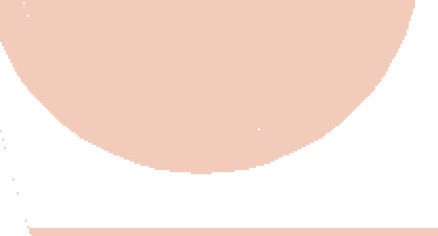

\section{ABBREVIATIONS}

\section{AD - acetabular depth, \\ AP- anteroposterior, \\ HTE - horizontal toit externe angle,}

\section{INTRODUCTION}

Osteoarthritis (OA) is one of the most common joint disorders worldwide (1). In addition to damage and loss of articular cartilage, patients present with remodelling of subarticular bone, osteophyte formation, ligamentous laxity, weakening of periarticular muscles, and, in some cases, synovial inflammation (2). Despite the prevalence of OA,
NSA - neck shaft angle,

OA - osteoarthritis,

VCE - vertical centre edge angle,

WBV-whole-body vibration

the extremely long and indolent course that characterizes the disease has resulted in great difficulty in evaluating its natural history (3). The pathological changes of acetabular anatomical parameters are considered as prevalent predisposing factors for the development of hip OA. Risk factors for acetabular dysplasia can be divided into person-level fac- 

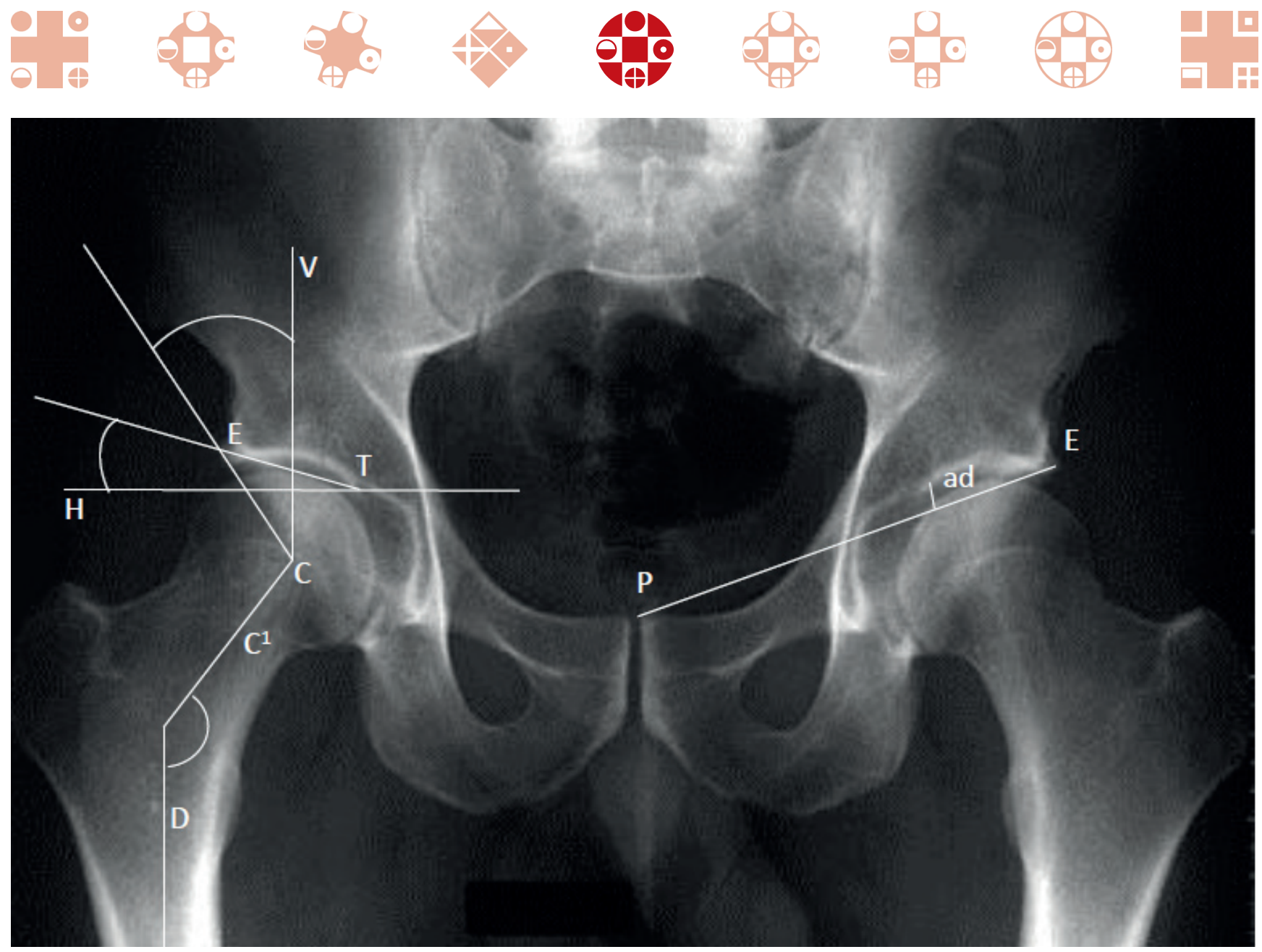

Figure 1. The VCE, HTE and neck shaft angles and acetabular depth.

\section{SUBJECTS AND METHODS}

tors (age, gender, obesity, genetics and diet) and joint-level factors (injury, malalignment and abnormal loading of the joints), which interact in a complex manner (1).

OA of the hip, the large weight-bearing joint, is a major source of pain and disability and represents the most frequent indication for total hip arthroplasty $(4,5)$. Recent reviews have concluded that there is evidence of a causal relationship between occupational mechanical exposures and primary hip OA (6-8). Workers with whole-body vibration exposure report a variety of physical disorders, both musculoskeletal and neurological (9). For example, some studies have found an association between working as a farmer and an increased risk of OA of the hip $(10,11)$. It has been suggested that exposure to the whole-body vibration caused by driving tractors and jumping up and down from the tractor cabin are of importance. On the other hand, a study by Järvholm and colleagues (12) showed no increased risk of OA in the hip for drivers of heavy vehicles such as tractor drivers.

The aim of this study was to investigate the relationship between the exposure of drivers of heavy vehicles to whole-body vibration and pathological changes in the anatomical parameters of acetabulum. We hypothesized that exposure to the whole-body vibration in drivers of heavy vehicles will be related with significant changes in the anatomical parameters of the hip components.
The study was performed among 120 subjects who were divided into two groups: the experimental group and the control group. The experimental group consisted of 60 male operators of heavy vehicles (workers employed in the car industry: three paving machine operators, 12 earth movers, 24 tractor and loading machine operators, 17 dumper drivers, two roller operators, and two roller graders) who were diagnosed with lumbar syndrome and were and were $52.2 \pm 2.5$ years old. The control group consisted of 60 male subjects of similar age, randomly selected from the general population, who were also diagnosed with lumbar syndrome.

Patients with a history of hip fracture and with hip deformities were excluded from the study.

The study was approved by the ethical committee of Clinical Center Kragujevac. After an explanation of the study's purposes, risks and benefits, all patients gave a written informed consent for participation in the study.

Anteroposterior (AP) radiographic views of the hips, standardized for position of the beam and radiographic penetration, were taken in the supine position with legs extended and internally rotated by $15^{\circ}$, with a distance of $101.6 \mathrm{~cm}$ between the $\mathrm{x}$-ray source and the radiographic film. The central radiographic ray was aligned to be perpendicular to the cassette, entering $5.08 \mathrm{~cm}$ superior to the pubic symphysis. Films with incorrect patient positioning were excluded from the analysis. 
Using a Plexiglas instrument with a ruler for joint space width measurement and protractors appropriate for measuring hip architectural angles $(13,14)$, the following parameters were measured (Fig 1):

1) The vertical centre edge angle (VCE), i.e., Wiberg's angle, is the angle formed by the vertical line drawn through the centre of the femoral head (point $C$ ) and the line $\mathrm{CE}$ (point $\mathrm{E}$ being the acetabular roof lateral rim). It measures the lateral covering of the femoral head by the acetabular roof and is considered insufficient (congenital dysplasia) when it is $\leq 20^{\circ}$ and excessive (coxa profunda) when it is $\geq 40^{\circ}$.

2) The 'horizontal toit externe' angle (HTE), i.e., the Tönnis angle, is the angle formed by the horizontal line drawn through point $\mathrm{T}$ (medial extremity of the acetabular roof) and the line TE. It measures acetabular roof acclivity and is considered too oblique when it is $\geq 12^{\circ}$.

3) The neck shaft angle (NSA) is formed by the neck axis and axis of the femoral diaphysis. It is indicative of coxa valga when it is $\geq 140^{\circ}$.

4) The acetabular depth (AD) is defined as the segment 'ad' that stretches from the deepest point of the acetabulum and the line drawn from the lateral extremity of the acetabular roof to the superior pubic angle. When the $\mathrm{AD}$ is $\leq 9 \mathrm{~mm}$, this is a criterion of dysplasia (acetabular insufficiency).

Statistical analyses were performed with statistical package SPSS 19.0 for Windows. After checking the normality of the data, the data were analysed using the t-test. The results are expressed as the mean \pm standard deviation. The alpha level for significance was set at $\mathrm{P}<0.05$.

\section{RESULTS}

According to the results presented in Table 1, the incidence rate of the pathological changes of acetabular parameters in the experimental group was higher than the incidence rate in the control group.

The mean values of VCE angles and the average values of $\mathrm{AD}$ in the experimental group were significantly lower than in the control group; however, in comparison with the

Table 1. Values of the VCE angle, HTE angle, neck shaft angle, and of acetabular depth.

\begin{tabular}{|l|c|c|c|}
\hline Parameter & $\begin{array}{c}\text { Experimental } \\
\text { group }\end{array}$ & $\begin{array}{c}\text { Control } \\
\text { group }\end{array}$ & $\begin{array}{c}\text { Significant } \\
\text { difference }\end{array}$ \\
\hline VCE angle (degrees) & $19.74 \pm 3.69$ & $25.8 \pm 4.82$ & $\mathrm{P}=0.000$ \\
\hline HTE angle (degrees) & $17.43 \pm 3.69$ & $12.17 \pm 4.19$ & $\mathrm{P}=0.000$ \\
\hline $\begin{array}{l}\text { Neck - shaft angle } \\
\text { (degrees) }\end{array}$ & $141.16 \pm 6.90$ & $134.93 \pm 6.52$ & $\mathrm{P}=0.000$ \\
\hline $\begin{array}{l}\text { Acetabular depth } \\
(\mathrm{mm})\end{array}$ & $11.02 \pm 3.38$ & $13.26 \pm 1.86$ & $\mathrm{P}=0.000$ \\
\hline
\end{tabular}

control group, the average values of HTE angles and NSA were significantly higher in the experimental group.

Acetabular dysplasia, considered as the condition when the VCE angle is $<20^{\circ}$, was found in 14 subjects in the experimental group and five subjects of the control group and was unilateral in all cases. Acetabular dysplasia, defined as a VCE angle $<20^{\circ}$ with an $\mathrm{AD}<9 \mathrm{~mm}$, was found in eight subjects from the experimental group.

\section{DISCUSSION}

$\mathrm{OA}$ is a multifactorial disease involving multiple systemic factors, such as metabolism, hormones, genetics, age, and sex, as well as local biomechanical factors, such as mechanical workload, body mass index (BMI), and acetabular dysplasia (15). Acetabular dysplasia is a condition wherein the acetabular roof is underdeveloped and remains vertically oriented and shallow, which results in a smaller surface area available for weight-bearing (16). The weight-bearing surface therefore receives a much larger force per unit area during walking and may experience early degeneration (16).

Numerous studies have shown that patients with marked hip dysplasia have an increased risk of hip OA since acetabulum abnormality leads to increased cumulative joint contact stress (17). Recent studies suggest that the mild acetabular dysplasia that persists into adult life may also be a significant factor in OA aetiology $(18,19)$. This aspect is especially important if a subject performs heavy physically demanding work. The presence of a subtle biomechanical abnormality, secondary to either joint incongruity (smaller acetabular depth) or decreased joint surface area (smaller CE angle), may increase joint stresses and consequently lead to OA (15). Studies on athletes from sports that subject joints to repeated high loading studies and individuals with physically demanding occupations (farmers, construction workers, metal workers, miners, pneumatic drill operators, etc.) support this assumption (20-24). Thus, the aim of our study was to explore the anatomical parameters of acetabulum in heavy vehicle operators in the car industry and note the risks of OA in this population.

To explore hip dysplasia, we used four parameters related to the shape of acetabulum and femur (VCE, HTE and NSA angle, AD) measured on AP radiographs of hips. The AP view of the pelvis is the single most important view for defining acetabular dysplasia and is the first radiographic step in the exploration of adult hip pain (14).

The VCE angle was first described by Wiberg in 1939 (25). This angle measures femoral head lateralization on the AP view of the pelvis and reports normal values if above $25^{\circ}$. Values between $20^{\circ}$ and $25^{\circ}$ are considered borderline, while a VCE angle of less than $20^{\circ}$ is considered diagnostic of acetabular dysplasia (14). Fourteen subjects from our experimental group had hip dysplasia according to the VCE angle value, resulting in an average VCE value of $19.74 \pm 3.69$ in this group. The incidence of a VCE angle $<20^{\circ}$ was signifi- 
cantly lower in the control group (five out of 60 subjects), resulting in a significant difference in the average value of this parameter between the two groups. In a Rotterdam study, the VCE angle was more strongly correlated with acetabular dysplasia in subjects performing high versus low physically demanding work (15), suggesting that this parameter is valid for hip dysplasia diagnosis in our experimental subjects.

In addition to a low Wiberg's angle, the radiographic diagnosis of hip dysplasia is usually made when the AD is lower than $9 \mathrm{~mm}$ (26). In our study, compared to controls, the experimental group had significantly lower AD values and eight out of 60 subjects fulfilled both requirements for dysplasia diagnosis (low VCE angle and AD). Previous studies have shown that there is a significant correlation between VCE angle and AD but also that both of these parameters are independent risk factors for hip dysplasia $(15,19)$. McWilliams and colleagues showed that as the CE angle and AD decreased, the risk of hip OA increased (19).

The Tönnis angle is used to evaluate the orientation of the acetabular roof in a coronal plane and the superior lateral coverage of the femoral head (14). It measures the angle of the weight-bearing surface and is considered normal when its value is approximately $10^{\circ}$, while values above $12^{\circ}$ point to a too oblique roof acclivity $(27,28)$. Values of the HTE angle above $10^{\circ}$ are frequently found in acetabular dysplasia (14). The results of our study show that the HTE angle was significantly increased in the experimental group and significantly different from the angle measured in controls. This puts much more stress on the affected hip, which is especially important in subjects performing hard work or subjects subjected to long-term WBV.

The mechanics of the hip joint are dependent on the relationship between the femoral head and the acetabulum (29). The NSA, also known as the caput-collum-diaphyseal angle or inclination angle, is an important anatomical measure for the evaluation and description of the geometry of the proximal femur and hip joint (30). Previous studies have proven its biomechanical and clinical significance in a number of orthopaedic conditions, such as hip dysplasia and OA, among other conditions. $(31,32)$. Femora are usually categorized as coxa vara when the NSA is $<120^{\circ}$, physiologicall when the NSA is $\geq 120^{\circ}$ to $<135^{\circ}$, and coxa valga when the NSA is $\geq 135^{\circ}(33,34)$. A recently published systematic review (35) revealed that the mean NSA in healthy adults $(5,089$ hips $)$ is $128.8^{\circ}\left(98-180^{\circ}\right)$, while in patients with OA $(1,230$ hips $)$ it is $131.5^{\circ}\left(115-155^{\circ}\right)$. Such a huge variance, the authors explained, is due to the central issue of inconsistency in the published methods of measurement. However, the average NSA angles in our study were pretty high in both groups and significantly higher in the experimental group, contributing to the overall pathological status of subjects exposed to WBV.

All the presented results suggest that pathological values of the measured anatomical parameters, i.e., hip dysplasia, are very common in populations working on heavy machines that produce WBV. Since cross-sectional studies in European populations have supported an association between hip dysplasia and hip OA (36-39), we thus may conclude that subjects from the experimental group are at a higher risk of developing OA than those from the control group.

\section{REFERENCES}

1. Palazzo C, Nguyen C, Lefevre-Colau MM, Rannou F, Poiraudeau S. Risk factors and burden of osteoarthritis. Ann Phys Rehabil Med 2016; doi: 10.1016/j.rehab.2016.01.006.

2. Litwic A, Edwards MH, Dennison EM, Cooper C. Epidemiology and burden of osteoarthritis. Br Med Bull 2013;105:185-99.

3. Goker B, Doughan AM, Schnitzer TJ, Block JA. Quantification of progressive joint space narrowing in osteoatrhritis of the hip: Longitudinal analysis of the contralateral hip after total hip arthroplasty. Arthritis Rheum 2000;43(5):988-94.

4. Rubak TS, Svendsen SW, Søballe K, Frost P. Total hip replacement due to primary osteoarthritis in relation to cumulative occupational exposures and lifestyle factors: a nationwide nested case-control study. Arthritis Care Res 2014;66(10):1496-505.

5. Rubak TS, Svendsen SW, Andersen JH, et al. An expertbased job exposure matrix for large scale epidemiologic studies of primary hip and knee osteoarthritis: the Lower Body JEM. BMC Musculoskelet Disord 2014;15:204.

6. Sulsky SI, Carlton L, Bochmann F, et al. Epidemiological evidence for work load as a risk factor for osteoarthritis of the hip: a systematic review. PLoS One 2012;7(2):e31521.

7. Vignon E, Valat JP, Rossignol M, et al. Osteoarthritis of the knee and hip and activity: a systematic international review and synthesis (OASIS). Joint Bone Spine 2006;73(4):442-55.

8. Lievense A, Bierma-Zeinstra S, Verhagen A, Verhaar J, Koes B. Influence of work on the development of osteoarthritis of the hip: a systematic review. J Rheumatol 2001;28(11):2520-8.

9. Johanning E. Whole-body vibration-related health disorders in occupational medicine--an international comparison. Ergonomics 2015;58(7):1239-52.

10. Walker-Bone K, Palmer KT. Musculoskeletal disorders in farmers and farm workers. Occup Med 2002;52:441-50.

11. Croft P, Coggon D, Cruddas M, Cooper C. Osteoarthritis of the hip: an occupational disease in farmers. BMJ 1992;304:1269-72.

12. Järvholm B, Lundström R, Malchau H, Rehn B, Vingård E. Osteoarthritis in the hip and whole-body vibration in heavy vehicles. Int Arch Occup Environ Health 2004;77(6):424-6.

13. Armbuster TG, Guerra J Jr, Resnick D, et al. The adult hip: an anatomical study. Part 1: the bony landmarks. Radiology 1978;128:1-10.

14. Delaunay S, Dussault RG, Kaplan PA, Alford BA. Radiographic measurements of dysplastic adult hips. Skeletal Radiol 1997;26:75-81. 
15. Reijman M, Hazes JM, Pols HA, Koes BW, BiermaZeinstra SM. Acetabular dysplasia predicts incident osteoarthritis of the hip: the Rotterdam study. Arthritis Rheum 2005;52(3):787-93.

16. Umer M, Thambyah A, Tan WT, Das De S. Acetabular morphometry for determining hip dysplasia in the Singaporean population. J Orthop Surg 2006;14(1):27-31.

17. Buckwalter JA, Anderson DD, Brown TD, Tochigi Y, Martin JA. The roles of mechanical stresses in the pathogenesis of osteoarthritis: implications for treatment of joint injuries. Cartilage 2013;4(4):286-94.

18. Murphy SB, Ganz R, Muller ME. The prognosis in untreated dysplasia of the hip. J Bone Joint Surg Am 1995;77:985-9.

19. McWilliams DF, Doherty SA, Jenkins WD, et al. Mild acetabular dysplasia and risk of osteoarthritis of the hip: a case-control study. Ann Rheum Dis 2010;69(10):1774-8

20. Cooper C, Croft P, Coggon D, Wickham C, Cruddas M. Farming and osteoarthritis of the hip. Acta Orthop Scand 1993;64(Suppl 253):58-9.

21. Croft P, Cooper C, Wickham C, Coggon D. Osteoarthritis of the hip and occupational activity. Scand J Work Envrion Health 1992;18(1):59-63.

22. Thelin A. Hip joint arthrosis: an occupational disorder among farmers. Am J Ind Med 1990;18(3):339-43

23. Cameron KL, Driban JB, Svoboda SJ. Osteoarthritis and the tactical athlete: A systematic review. J Athl Train 2016; Apr 26. [Epub ahead of print]

24. Lane NE, Buckwalter JA. Exercise: a cause of osteoarthritis? Rheum Dis Clin North Am. 1993;19(3):617-33.

25. Wiberg G. Studies on dysplastic acetabula and congenital subluxation of the hip joint. Acta Chir Scand 1939;58:5-135.

26. Daysal GA, Goker B, Gonen E, et al. The relationship between hip joint space width, center edge angle and acetabular depth. Osteoarthritis Cartilage 2007;15(12):1446-51.

27. Tönnis D, Brunken D. Differentiation of normal and pathological acetabular roof angle in the diagnosis of hip dysplasia. Evaluation of 2294 acetabular roof an- gles of hip joints in children. Arch Orthop Unfallchir 1968;64(3):197-228.

28. Tönnis D. Normal values of the hip joint for the evaluation of X-rays in children and adults. Clin Orthop Relat Res 1976;(119):39-47.

29. Reikerås $\mathrm{O}$, Høiseth $\mathrm{A}$. Femoral neck angles in osteoarthritis of the hip. Acta Orthop Scand 1982;53(5):781-4.

30. Wright D, Whyne C, Hardisty M, Kreder HJ, Lubovsky O. Functional and anatomic orientation of the femoral head. Clin Orthop Relat Res 2011;469(9):2583-9.

31. Sugano N, Noble PC, Kamaric E, Salama JK, Ochi T, Tullos HS. The morphology of the femur in developmental dysplasia of the hip. J Bone Joint Surg Br 1998;80(4):711-9.

32. Mills HJ, Horne JG, Purdie GL. The relationship between proximal femoral anatomy and osteoarthrosis of the hip. Clin Orthop Relat Res 1993;288:205-8.

33. Boese CK, Jostmeier J, Oppermann J, et al. The neck shaft angle: CT reference values of 800 adult hips. Skeletal Radiol 2016;45(4):455-63.

34. Guevara CJ, Pietrobon R, Carothers JT, Olson SA, Vail TP. Comprehensive morphologic evaluation of the hip in patients with symptomatic labral tear. Clin Orthop Relat Res 2006;453:277-85.

35. Boese CK, Dargel J, Oppermann J, et al. The femoral neck-shaft angle on plain radiographs: a systematic review. Skeletal Radiol 2016;45(1):19-28.

36. Jacobsen S, Sonne-Holm S, Søballe K, et al. Hip dysplasia and osteoarthrosis: a survey of 4151 subjects from the osteoarthrosis substudy of the Copenhagen city heart study. Acta Orthop 2005;76:149-58.

37. Jacobsen S, Sonne-Holm S. Hip dysplasia: a significant risk factor for the development of hip osteoarthritis. A cross-sectional survey. Rheumatology 2005;44:211-18.

38. Reijman M, Hazes JM, Pols HA, et al. Acetabular dysplasia predicts incident osteoarthritis of the hip: the Rotterdam study. Arthritis Rheum 2005;52:787-93.

39. Jessel RH, Zurakowski D, Zilkens C, et al. Radiographic and patient factors associated with pre-radiographic osteoarthritis in hip dysplasia. J Bone Joint Surg Am 2009;91:1120-9. 